\title{
VALUE AND BARRIERS IN THE CREATION OF INTELLECTUAL PROPERTY IN ADVANCED MANUFACTURING: A COUNTRY COMPARISON ${ }^{12}$
}

\section{Keywords:}

Key Enabling Technology, Intellectual property rights, Patent value, R\&D partners.

\section{Purpose:}

The basic aim of this research is to determine to what extent intellectual property owners of advanced manufacturing technologies compensate the disadvantages of their small size and peripheral company location by innovations in these areas.

\section{Design/methodology/approach:}

We developed an empirical study of patents from two completely different economic areas, a central and a peripheral one, represented by Germany and Spain, respectively, in the domain of the Key Enabling Technology (KET) of advanced manufacturing technologies in robotics and automation. From the population of 211 Spanish patents granted and a random sample of 500 German patents, from the files of the US Patent and Trademark Office, we developed a series of logistic regression models.

\section{Findings}

Judging from the predicted possibilities to develop a patent with more citations, a proxy for its value, the study shows that whereas big companies from central locations do not obtain more heavily cited patents from sharing their R\&D activity with other firms or research institutes, smaller manufacturing firms in peripheral areas, namely, Spain, may find this advantageous. Additionally, patents containing fewer cited articles and citations of previous patents, tend to be cited more frequently. Finally, this same outcome is also observed with patents showing shorter time between the application and grant.

\section{Originality/value}

To the best of our knowledge, this is the first study on patent value which examines the KET of advanced manufacturing technologies in robotics and automation, comparing a central to a peripheral geographic environment, and determining the number, diversity and size of patent assignees. Our results prove relevant in general for manufacturing businesses, especially in the Machine-Tool and machinery producing industry. Overwhelmingly, these firms tend to be SMEs basing their marketing activity entirely on a Business-to-Business (B2B) focus, and facing serious obstacles for R\&D activity.

\footnotetext{
${ }^{1}$ We are deeply thankful to Prof. Loet Leydesdorff for his patent search programs, available to all at his personal homepage, www.leydesdroff.net/software , and for his kind orientations by email for correct use and retrieval of the data.

${ }^{2}$ Access to published version: 10.1108/JBIM-07-2018-0207
} 


\section{Introduction $^{3}$}

Technology transfer is a key element in the development of innovations. Companies benefit from the influence of agents and factors operating nearby. According to Rogers $(1983,1989)$, in order to succeed technology transfer must obtain help from change agents establishing communication from innovation producers to users, adequate funding, and a research system oriented to finding solutions (Rogers 1989, 2002). These elements are hardly ever evenly distributed across geographic areas. In fact, nations or regions play a determinant role in providing an environment that is "forward-looking, dynamic and challenging” in the case of certain industries (Porter 1990, p. 73).

It is argued that, to some extent, the competitive advantage of a firm is reliant on the attributes of the region or nation where it is located (Patel and Pavitt 1991). New industries and technologies evolve more easily in places where these are related to preexisting ones (Hidalgo, et al. 2007, Montresor and Quatraro 2017). According to Porter, firms benefit from the competitiveness of nations due to factor conditions, such as skilled labor, or infrastructure, demand conditions from home markets, the presence of related and supporting industries, and lastly, the conditions governing how firms are created, managed or how these compete at the domestic level (Porter 1990).

In the case of intellectual property rights, data show a markedly uneven distribution in the number of patent applications, both from resident and non-resident applicants across types of firms and countries or regions (WIPO 2017). There is ample evidence that the majority of patenting records concentrate in a small number of countries and worldleading corporate innovators (Dernis et al. 2015), notably in the case of information and communication technologies (Daiko et al. 2017). For instance, in 2017, with 25,490 patent applications, Germany accounted for $15 \%$ of the total amount of applications filed to the European Patent Office, with the US ranking first (26\%) and Japan third (13\%). In contrast, the second country we used in our comparative study, Spain, ranked $16^{\text {th }}$, representing approximately 1\% or 1,676 applications (WIPO 2017, Oficina Española de Patentes y Marcas, 2018). These differences between the two countries remain even when the higher number of enterprises registered in Germany is taken into account.

Recent studies on the determinants influencing the location choice of multinationals show that there is a combination of firm-specific, along with environment factors from supply and demand, technology, and institutional attributes present in the home and host economies (Belberdos et al. 2016, p. Dosso and Vezzani 2015). Supply side factors include the type of R\&D activities, firm size and corporate performance, location of production activities and other specific managerial and organizational practices. For their part, the environment factors comprise elements both from the home and host countries, such as market size, growth potential and purchasing power, the presence of high quality infrastructure and skilled human resources, and agglomeration forces, resulting from clusters, scientific parks, or outstanding innovative or creative cities (Dosso and Vezzani 2015).

However, can these national and corporate differences also be extended to inventions from assignees present in different countries, but operating within the same technology? Are these differences also noticeable for the case of the value of their patents? Most importantly, could firms, especially SMEs from peripheral areas, find feasible ways to reduce these limitations? Our study aims to answer these questions. We particularly study

\footnotetext{
${ }^{3}$ We thank the valuable suggestions from the Editorial Board and the reviewers, directed towards improving the quality of our paper.
} 
the effect of the number and diversity of assignees on a patent as antecedents that may counter the advantages that big and centrally located organizations have, according to previous research (Almeida, 1996, Hidalgo et al. 2007, Schiessler 2015).

In order to study these phenomena in a strictly comparative way, we compared the value of patents belonging to assignees across two notably different country sets: patents from Germany, representing a central geographic area of R\&D, and patents from Spain, representing a peripheral country. We based our comparative analysis on three dimensions: (1) the same particular technology, namely new manufacturing technologies in robotics and automation (2) a common general geographic and institutional environment, the European Union, to which the two compared countries belong, and (3) the same granting office from a third country, the U.S. Patent and Trademark Office (henceforth, USPTO).

Evidence on whether or not large firms benefit more from the patent system is contradictory (Holgersson 2013, Jensen and Webster 2006), or varying depending on the industry (Doi 1996). Whereas some empirical studies find evidence showing that larger firms have more propensity for patenting (Arundel 2001, Iversen 2003, Schiessler 2015), other analyses find evidence showing that smaller firms experience higher R\&D yields (Acs and Audretsch 1990, Bound et al. 1984). It is well known in the literature that patenting as a means to protect intellectual property is more accessible to companies exceeding a critical size, notably large corporations, in contrast to SMEs, especially with respect to resources for monitoring and enforcing their patents (Holgersson 2013, Schiessler 2015). Consequently, it is necessary that SMEs find ways to overcome these disadvantages. We obtain indications suggesting that a careful selection and partnership with research institutes is an option conducive to the production of more valuable patents, especially for firms located in peripheral areas for R\&D. The implications for managers, countries, and institutions are clear, as we state in our concluding remarks.

We develop our study in this paper as follows. The next section discusses the selected field of new manufacturing technologies in robotics and automation with greater precision, and explains in greater detail the use of data from granted patents. Next, we present our model and pose the hypotheses based on the previous literature and our research aims. Following this, we explain the data sets of patents studied and complete the logistic regression analysis aimed to test our model, and present our results. We then go on to the discussion and conclusions, and the implications for managers and institutions. We finish by explaining the limitations of our analysis and the suggestions for future areas of improvement.

\section{Literature review on resources and capabilities for $R \& D$ in new manufacturing technologies}

General-purpose technologies (GPTs) are technologies "characterized by the potential for pervasive use in a wide range of sectors and by their technological dynamism" (Bresnahan and Trajtenberg 1995, p.84). Some previously recognized qualities of these new technologies are: (1) their potential for spurring changes to the status quo across businesses, sectors or regions (Rotolo, Hicks and Martin 2015), (2) their capital role in the history of innovation (Aschhoff et al. 2010), (3) their ability for open innovation processes that bring solutions to specific industrial problems (Larsen, et al. 2011), (4) their capacity for assuring the future competitiveness and prosperity of states (Sörvik et al., 2013), or (5) their capacity for converging "interest between Market requirements and Industrial challenges” (Scalia et al. 2017, p.12). 
However, the use of different names in the academic world and policy-making, such as Emerging technologies (Rotolo et al. 2015), or Key Enabling Technologies (KETs) (Montresor and Quattraro 2017), together with differences in the emphasis put on their distinguishing features (Lipsey et al., 2015) have resulted in a certain lack of definition.

According to the European Commission, KETs are capital to "underpin the shift to a greener economy, modernizing Europe's industrial base, and driving the development of entirely new industries.” (European Commission 2014) ${ }^{4}$. KETs are characterized as knowledge intensive technologies, with a high R\&D level, reliant on fast innovation cycles, and requiring high capital expenditure and highly qualified (i.e. a trained-towardsresearch) staff. By nature, KETs are multidisciplinary, cutting across other fields or technological solutions, with a tendency to converge and integrate (Van de Velde et al., 2015). In short, these are technologies allowing a wide variety of applications in the form of innovative products or processes. These technologies feed and create value in many industrial value chains and sectors in a heterogeneous way, from materials, equipment or devices to products and services. Finally, KETs are considered key to the modernization of the industrial base and conductors for the creation of new companies.

The European Commission recognizes a total of six KETs: micro and nanoelectronics, nanotechnology, industrial biotechnology, advanced materials, photonics, and advanced manufacturing technologies ${ }^{5}$. Each has its own peculiarities with respect to the distance from basic to applied research, its prevalence by regions or countries, or its present relevance for economic sectors. Particularly due to its importance in manufacturing industries, we selected the KET of advanced manufacturing technologies for our empirical analysis. By 2010, the largest EU27 manufacturing subsectors where this KET was present were, among others: machinery and equipment manufacturers, food, fabricated metal products, motor vehicles, and chemicals (Butter et al. 2014, p.32). Precisely, an important share of the industrial activity within these KETs belongs to machine-tool and machinery producing companies, which base their commercial activity entirely on Business-to-Business marketing and sales.

In this context, we aim to distinguish value in the production of intellectual property rights in this particular KET, stemming from companies' efforts to team up with other R\&D partners, and controlling for their size and location. Operationally, we took our indicator of value from the number of forward citations of granted patents, a variable frequently used as a proxy of their value (Harhoff et al. 1999, 2003, Jaffe and Rassenfosse 2017, Petruzzelli et.al.2018).

\section{Hypotheses development}

\section{Size obstacles to $R \& D$ and partnership agreements to counter them}

According to the Resource-Based View, firms are "heterogeneous in terms of their resources and internal capabilities” (Peteraff 1993, p. 179). Following the same reasoning on the one hand, long-lasting and difficult-to-imitate R\&D resources and capabilities help firms to outperform others in the same industry (Barney 1986, 1991). On the other hand, in the face of a particular technological advancement, the forefront scientific nature of KETs entails important entry barriers, above all for small and medium-sized (SME) firms, and firms with low R\&D capabilities. Companies need to have a focused, critical

\footnotetext{
${ }^{4}$ https://ec.europa.eu/growth/industry/policy/key-enabling-technologies en

5 https://ec.europa.eu/growth/industry/policy/key-enabling-technologies_en
} 
knowledge base and high learning, or absorptive, capabilities within specific fields in order to acquire, develop and exploit KET-based advancements successfully (Cohen and Levinthal 1989, 1990).

Zahra and George (2002) recognize absorptive capacity in organizations as a learning process consisting of four dimensions: acquisition, assimilation, transformation and exploitation. Firms in general must elevate their abilities in all these four dimensions in order to achieve innovative solutions (Tsuji et al. 2018). However, these resources and capabilities for innovation are not entirely internal to firms but can be attained, at least partly, from knowledge-sharing routines (Dyer and Singh 1998) developed through dyads or networks of research partners. Secondly, firms do not develop innovative ideas in a vacuum, but rather they rely on external sources of information, and combine these with their internal sources (Spithoven, Vanharverbeke and Roijakkers 2013). However, smaller firms have fewer human resources to screen innovative ideas from the environment for valuable information than larger firms (Van de Vrande et al. 2009; Dahlander and Gann 2010; Chesbrough 2011). SMEs are usually hindered by "internal and external structural impediments", and lack the critical absorptive capacity "to invest in R\&D and search for opportunities for partnership" (Wynarczyk, Piperopoulos and McAdam 2013, p. 244). Thus, these firms need to team up with other organizations, universities and research institutes (von Hippel 1988, Verspagen 2000), in order to counter the impediments caused by their small size. The presence of more assignees sharing the costs of patent development helps individual firms to overcome these obstacles, resulting in higher quality intellectual property, ascertained in the form of patents with forward citations. Precisely, SMEs interacting along with other firms, but also with governments, semi-public research institutes and universities, gain knowledge from the activities of basic and applied research, innovation, invention and diffusion in ways that are not 'linear' (Kline and Rosenberg 1986).

Notwithstanding the aforementioned reasons for SMEs to join efforts with R\&D partners, we must bear in mind the potential problems appearing from the indivisibility, inappropriability and uncertainty of resource allocation in the market of intellectual property rights (Arrow 1962). Property rights can only provide a partial barrier against information spillovers of an innovation, and the mere act of disclosure of the idea through a patent is an act of disclosure, and appropriation of knowledge from third parties without payment. Also, the potential buyer (or would-be-partner in an R\&D work leading to a patent) of the innovation will base their decision to buy or participate "on less than optimal criteria”. Finally, "it leaves unsolved the problem of the purchaser's ability to judge the value of the information he buys in advance". In summary, despite the existence of intellectual property legal systems, "there is difficulty involved in creating a market for information" (p. 616). Therefore, all these difficulties run counter to the decision from SMEs to join other parties with the initiative to share innovation benefits and costs.

By the same token, big firms find incentives to conduct the process towards innovative ideas leading to new products "with many projects going on, each small in scale compared with the net revenue of the corporation" (Arrow 1962, p.616), and avoid sharing the R\&D costs especially if there are good prospects for profits. Finally, as a warning to offers to enter sharing the benefits and costs of a patent development process, SMEs should consider information asymmetries and the risks of the original developer taking an opportunistic stance (Akerlof 1970, Pisano 1990) especially when a high risk or cost relative to the outcomes is predicted.

Hence, we pose the following hypotheses: 
H1: The number of assignees in a patent is negatively linked to its value.

$\mathrm{H} 2$ : The more diverse the assignees we find in a patent, the less valuable it is.

Contrary to the arguments leading us to hypothesize against teaming-up with firms, in the case of foundations or public entities such as research institutions, the perceived risk of opportunism from the idea developers is neutralized by the absence of competition from these entities and their non-for-profit focus. Hence:

H3: Patents which have a research institute among the assignees tend to be more valuable.

Finally, derived from the reflections made on the advantages from company dimension, we state:

H4: Patents from larger assignees tend to be more valuable.

\section{Conditioning effects of the location of $R \& D$ activities}

An added difficulty of KETs is that R\&D and knowledge transfer based on these advancements entail a variable degree of difficulty and uncertainty, depending on the country or region where a company performs its R\&D activities. The forefront scientific nature of KETs supposes potential entry barriers for SMEs and firms with low R\&D capabilities. Organizations need to have a focused, critical knowledge base and high learning capabilities within specific fields (Cohen and Levinthal 1989, 1990) in order to acquire, develop and exploit KET-based advancements successfully. Thus, finding readily available resources and capabilities in the region or place, or the network of relatedness among products in a place (Hidalgo et al. 2007), offering access to some vital resources “at arm's-length” (Dyer \& Singh 1998), becomes a significant advantage for companies with R\&D activity located in these geographically central areas of innovation. Hence, our hypothesis is:

H5: The country of assignee plays a significant role in the value of a patent.

\section{Time effects}

According to Altshuller (2007), technologies tend to evolve in a series of stepwise improvements and changes, until becoming mature and then entering obsolescence. Technologies that are still in their infancy tend to engender more radical innovations and innovative products, whereas those in a mature stage bring a lower number of innovations (Scalia et. al. 2017, p. 62). Nevertheless, radicalness of innovations does not necessarily equate to innovation value. Innovations that are valuable for firms do not always originate from the adoption of nascent technologies. Assuming the contrary is known as recency bias, that is, an adverse vision of old knowledge and hence, an undervaluation of potential benefits from these mature technologies (Katila, 2002, as cited from Petruzzelli et.al. 2018). These ideas suggest that the link between time and innovation value is not necessarily linear. In fact, there is some consensus on the existence of an inverted 'U'shape between maturity and the number of forward citations (Petruzzelli et.al.2018).

In our model we incorporated two consecutive time periods separately: first, the time elapsed from application to grant by the USPTO. Second, the time from the grant date to the present time. In the first period, a longer time span may be an indicator of the obstacles and difficulties that applicants must overcome in order to receive the patent grant. In other 
words, the time required for approval may be an indicator of poor quality and hence, of fewer citations for the patent in the future. Thus, we pose:

H6.1: Time from file to grant is negatively linked to the value of a patent.

Referring to the second period of time, we must stress that we are not focusing on the effect in a medium to long time span, as the KET we studied is, in essence, new. In fact, "citations analysis will never be usable for evaluation of current or very recent innovations", because "substantial time is needed after a patent is granted to accumulate significant information about its citations" (Hall, et al., 2005, p.31). However, it is clear that this is also the case with academic article citations; time always acts in favor of patent forward citations, even for nascent or very new technologies. Thus, we pose:

H6.2: Time from grant date is positively linked to the value of a patent.

\section{Fields of technology}

The number and variety of technology classes in a patent may be a measure of the scope or breadth of prior art in a patent (Alcácer and Gittelman 2006). The international patent classification (IPC) codes indicate the fields of technology to which the invention of the patent under scrutiny pertains (OECD 2009, van Raan 2017). These codes are fixed by patent examiners (OECD 2009).

The number of four digit IPC codes has been taken as a proxy of the patent scope in previous research (Lerner 1994, Harhoff et al. 2003). A virtue of patent data for social science research lies in the technology-based classification system that allows researchers to place patents, inventors and organizations in a technology base, and that is "not derived from sales or other economic data that one may be trying to relate to invention" (Jaffe and Rassenfosse 2007, p. 1361).

It is not clear if a more "general” patent will be detrimental or not. Hall et al. (2005) suggest that this may be the situation for a specialist firm but not for a conglomerate, due to the fact that the former will not be able to appropriate the spillovers to other fields, whereas the latter will. In their study on a sample of German patents, Harhoff et al. (2003) find no association between the number of 4-digit IPC classifications and the value of granted patents. Previous research on patent law shows that the question of patent scope becomes critical and difficult for examiners in the case of emergent disciplines that are pursued by industries with an incipient product market competition (Merges and Nelson 1990). Thus, considering the situation of new technologies, such as that represented in our study, we infer that the higher the number of classes in a patent, the more problematic it will be for patent applicants to convince examiners and obtain grant status.

In summary, to the best of our knowledge, there is no clear coincidence between the approach used to measure patent breadth and the results of this factor in empirical studies. However, considering the problematic situations that assignees of a broad patent will face both during approval and later, in defending the exclusivity of their claims in cases of infringement, we pose the following hypothesis:

H7: The higher the number of classification codes in a patent, the less valuable it is.

\section{Patent and non-patent citations}


For their part, patent citations primarily serve the legal purpose of indicating which parts of the innovation idea described in a patent can be claimed by an applicant, and which have previously been claimed in other patents (Verspagen, 2000, Michel and Bettels, 2001, van Raan 2017). In economic research, patent citations have been repeatedly used as indicators of knowledge spillovers (Almeida 1996, Alcácer and Gittelman 2006), value of patents (Harhoff et al. 1999, 2003), or firm market value (Griliches 1981, Hall et al. $2005)^{6}$.

In order to succeed in obtaining a patent grant, the idea presented in the patent application must: (a) be novel, (b) have inventive activity, and (c) have industrial applicability. Thus, during the application process, this 'patentability search process' aims not to miss any important technical document (especially including other patents) and looks to make sure there are no important limitations in the scope of the claims from the applicants (Michel and Bettels, 2001).

Contrary to non-patent citations (above all in scientific articles), cited patents bear legal consequences for the patent applicants, and are of special concern to patent examiners (Lerner and Seru 2017, van Raan 2017). Hence, patent citations are not only added by the applicants of a patent, but by patent examiners during the revision period. Relevant results have been found by differentiating between citations added by applicants and those added by examiners. Whereas the former are more focused on detaching their application claims from previous patents, the latter tend to be guided by the opposite idea (Cotropia et al. 2013). It is also worth mentioning that the work performed by examiners adding references in an application is far from negligible: references from examiners account for $6 \%$ of the cited non-patent literature and 34\% of patents in an application (p.846).

Maybe the clearest reasoning regarding the effects of the number of citations comes from Jaffe and Rassenfosse (2017). Drawing from a previous study led by Trajtenberg et al. (1997), these authors explain: "trivial inventions tend to be more extensively rooted on previous ideas, whereas more basic inventions are less incremental by nature, and thus have fewer identifiable antecedents". The latter have "less historical background" and thus, tend to cite fewer patents (p.1363). Therefore, along these lines, we pose:

H8.1: The number of scientific articles cited in a patent has a significant negative effect on its value.

H8.2: The number of patents cited in a patent has a significant negative effect on its value.

\section{Method and analysis}

\section{General variables and descriptive results}

For the case of the Spanish set, we took the census of granted patents in the US Patent and Trademark Office from the KET of Advanced manufacturing technologies, in robotics and automation (See Appendix 1). Given the wide variety of technologies involved in this KET, for the purposes of our empirical analysis, we concentrated on the sub-type of robotics and automation. More specifically, in its identification we used the European Commission's Road Map of cross-cutting KETs (Ro-cKETs), associating one or more KETs to a specific International Patent Classification (IPC) string, as described by Scalia et al. (2017, p.60 Table 4. See Appendix 1).

\footnotetext{
${ }^{6}$ For a comprehensive revision of patent citations, see Jaffe and Rassenfosse (2017)
} 
The population retrieved from USPTO databases was 211 patents containing an assignee from Spain. The classification of assignees by country is a variable provided by the USPTO records. In the case of the German set, the population at the time of the study comprised 11,797 patents for the case of this selected KET. We opted for a systematic random sample of 500 patents, respecting the quota proportions from each year of the set. No retrieved patent belongs to assignees from both countries at the same time.

In order to download and complete both sets of patents, we used Loet Leydesdorff's software for patent retrieval and database generation (available from his own homepage at www.leydesdroff.net/software). We transformed the original fields present in each patent into dichotomous variables, setting the median value of each original variable as the class boundary. Table 1 summarizes the descriptive values of the variables used in the model. All the variables in this table, except for the assignee's size in each patent, were obtained from the retrieved patents. The largest assignee's size for each patent is the number of employees in the largest organization, and was obtained by using several alternative sources. We searched for each assignee's name in Wikipedia or SABI database (from Bureau van Dijk) for the case of the Spanish population of patents. For the case of the German sample, we consulted Wikipedia, D\&B-Hoovers ${ }^{7}$, and North Data ${ }^{8}$. In a number of cases, it was necessary to look up the corporate results ${ }^{\circ}$ on the assignee's webpages. In every case, we looked for the last fiscal year available. Finally, we also performed this retrieval of assignees in order to control for those firms or institutions that went bankrupt, were absorbed or merged. Only in the case of two patents belonging to the same bankrupt and extinguished Spanish firm, were the corresponding patents eliminated from the sample. This decision left the number at 209 Spanish patents, 709 in total.

The following table summarizes the main descriptive statistics in both sets:

Table 1. Main descriptive values of patents

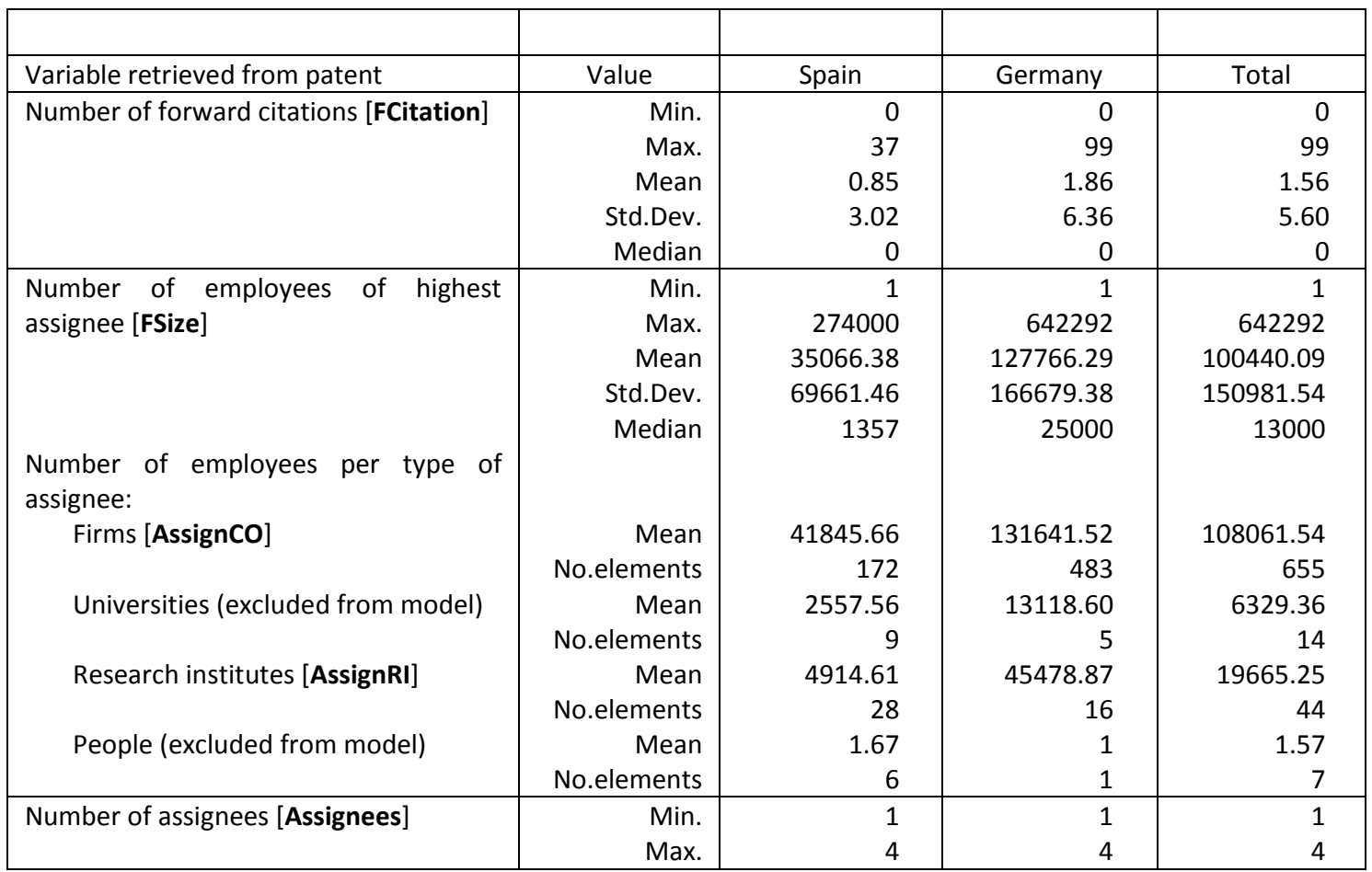

\footnotetext{
${ }^{7}$ www.hoovers.com

$8 \overline{\text { www.northdata.de }}$
} 


\begin{tabular}{|c|c|c|c|c|}
\hline & $\begin{array}{l}\text { Mean } \\
\text { Std.Dev. } \\
\text { Median }\end{array}$ & $\begin{array}{r}3.96 \\
0.34 \\
1\end{array}$ & $\begin{array}{r}3.67 \\
0.27 \\
1\end{array}$ & $\begin{array}{r}1 \\
0.29 \\
1.06\end{array}$ \\
\hline \multirow{5}{*}{$\begin{array}{l}\text { Number of classes from the International } \\
\text { Patent Classification [IntClass] }\end{array}$} & Min. & 1 & 1 & 1 \\
\hline & Max. & 18 & 17 & 18 \\
\hline & Mean & 3.30 & 3.16 & 3 \\
\hline & Std.Dev. & 2.56 & 2.43 & 3.22 \\
\hline & Median & 3 & 2 & 2.48 \\
\hline \multirow[t]{5}{*}{ Number of cited patents [PatRef] } & Min. & 0 & 0 & 0 \\
\hline & Max. & 81 & 192 & 192 \\
\hline & Mean & 13.82 & 14.1 & 14.03 \\
\hline & Std.Dev. & 11.00 & 13.64 & 12.90 \\
\hline & Median & 11 & 12 & 12 \\
\hline \multirow[t]{5}{*}{ Number of cited scientific articles [LitRef] } & Min. & 0 & 0 & 0 \\
\hline & Max. & 56 & 23 & 56 \\
\hline & Mean & 2.28 & 1.69 & 1.86 \\
\hline & Std.Dev. & 5.02 & 2.87 & 3.64 \\
\hline & Median & 1 & 1 & 1 \\
\hline \multirow{5}{*}{$\begin{array}{l}\text { Time from application to grant (in years) } \\
\text { [TimeAppl] }\end{array}$} & Min. & 0.80 & 0.61 & 0.61 \\
\hline & Max. & 11.05 & 9.91 & 11.05 \\
\hline & Mean & 3.96 & 3.67 & 3.75 \\
\hline & Std.Dev. & 1.76 & 1.60 & 1.65 \\
\hline & Median & 4.02 & 3.44 & 3.55 \\
\hline \multirow{5}{*}{$\begin{array}{l}\text { Time from grant date to present (in } \\
\text { years) } \\
\text { [TimeToday] }\end{array}$} & Min. & 0.06 & 0.06 & 0.06 \\
\hline & Max. & 12.09 & 12.14 & 12.16 \\
\hline & Mean & 3.83 & 4.48 & 4.28 \\
\hline & Std.Dev. & 2.98 & 3.41 & 3.30 \\
\hline & Median & 3.03 & 3.64 & 3.25 \\
\hline \multirow[t]{2}{*}{ Population and sample elements: } & $\mathrm{N}$ & 211 & 11,797 & \\
\hline & $\mathrm{n}$ (sample) & 209 & 500 & \\
\hline
\end{tabular}

Note: In brackets, the names of the dummies from each original variable, finally included in the model.

For the binary logistic regression, the dependent variable considered is the number of patent forward citations, dichotomized into zero citations, versus one or more. Two reasons explaining this dichotomization are, firstly, the fact that more than $62 \%$ of the total set of patents have no forward citations, and second, the limited size of the total and country sets for the devised model.

The independent variables are, first, the assignees' country (Country). For its part, the number (Assignees) and types of assignees give way to a collection of variables considered in our model. Firstly, a dummy variable (AssignCO) acknowledging that there is at least one assignee from the following legal entities: either a public limited company, a private-owned company, a limited partnership company or a cooperative. A second dummy (AssignRI) considering the cases of patents containing at least one research institute among its assignees ${ }^{9}$. A third dummy produced (VarAssign) from the original field of assignees, which is a two-level variable acknowledging the diversity of assignees, meaning 1 if there is only one entity or more of a same type, and 2 if it contains at least two assignees of different types. The types of assignees considered are: the aforementioned different types of firms, research institutes, universities or people. Each circumstance is acknowledged with a particular dummy. However, the former two categories (i.e. universities and people) were excluded from our study due to the low frequencies obtained.

\footnotetext{
${ }^{9}$ The most prominent research institute in Spain is the Consejo Superior de Investigaciones Cientificas (CSIC). For its part, one of the best-known German research institutes is the Fraunhofer-Gesellschaft zur Forderung der Angewandten Forschung E.V.
} 
The number of categories from the classification of the International Patent Office (WIPO 2018), also available from USPTO, is represented using a dummy (IntClass), distinguishing two types of patents, namely those having up to two 4-digit codes, versus those having three or more.

A variable measuring the time elapsed in years from the application file date to the issue (grant) date was converted into a dummy variable (TimeAppl), differentiating patents of less than the median time from patents of more than the median time, set at 3.55 years. For its part, the second time variable (TimeToday) comprises the time from the issue date to the current date (set on May 3, 2018), distinguishing patents in two groups with the median equal to 3.25 years as threshold.

Two variables measure the works cited in each patent. First, the number of scientific articles, converted into a dummy (LitRef), with the median set as threshold (1.86 referenced articles), and second, the dummy transformation (PatRef) from the number of cited patents, with its median value (14.03 patents).

Finally, we consider the size of the biggest assignee within the patent, by number of employees (FSize). The criterion for considering the size of the assignee firm or entity led us to identify the parent firm or group name in every patent. The reason for this decision is backed by prior literature relating size to more capabilities or resources dedicated to patent maintenance and vigilance, and exercising more strength and experience in case of litigation (Schiessler 2015).

\section{Results from the binary logistic regressions}

We obtained seven binary logistic regression functions. In general, the variables that are common give similar results. Models 1 to 5 are configured to show the marginal effects from the different number, variety and type of assignees. Models 6 and 7 study the effects of the number of cited articles and cited patents, respectively. Centering on the main effects included in all the models, and particularly the country effect, except for Model 3, the results show that the assignee's country is a highly significant factor, in detriment of patents belonging to Spanish assignees. Significant coefficients range from -1.282 in Model 7 to -2.213 in Model 6, meaning propensities from $72.3 \%$ up to $89.16 \%$ lower for the outcome if belonging to the patents with forward citations, in the case of the Spanish set. Thus, Hypothesis H5 stating that the assignees' country plays a significant role in the value of a patent is confirmed, in detriment of the country considered as peripheral in the selected KET (Spain in our dataset).

Table 2. Maximum likelihood estimated logistic regression coefficients

\begin{tabular}{|c|c|c|c|c|c|c|c|}
\hline & (1) & (2) & (3) & (4) & (5) & (6) & (7) \\
\hline Country = Spain & $\begin{array}{c}-1.295^{* * * * *} \\
(0.193)\end{array}$ & $\begin{array}{c}-1.528 * * * * \\
(0.217)\end{array}$ & $\begin{array}{c}0.573 \\
(0.647)\end{array}$ & $\begin{array}{c}-1.307 * * * * \\
(0.182)\end{array}$ & $\begin{array}{c}-2.017 * * * * \\
(0.358)\end{array}$ & $\begin{array}{c}-2.213^{* * * * *} \\
(0.358)\end{array}$ & $\begin{array}{c}-1.282 * * * * \\
(0.211)\end{array}$ \\
\hline $\begin{array}{l}\text { AssignCO=No. } \\
\text { Firms }\end{array}$ & & $\begin{array}{c}-1.254 * * * \\
(0.476)\end{array}$ & & & & & \\
\hline FSize $<13,000$ & $\begin{array}{l}-0.300^{*} \\
(0.156)\end{array}$ & $\begin{array}{c}-0.362^{* * * *} \\
(0.162)\end{array}$ & $\begin{array}{c}-0.369 * * * \\
(0.170) \\
\end{array}$ & $\begin{array}{c}-0.564 * * * * \\
(0.144)\end{array}$ & $\begin{array}{c}-0.522^{* * * *} \\
(0.171)\end{array}$ & $\begin{array}{c}-0.561 * * * * \\
(0.171)\end{array}$ & $\begin{array}{l}-0.285^{*} \\
(0.170)\end{array}$ \\
\hline $\begin{array}{l}\text { AssignRI=No } \\
\text { Res.Institute }\end{array}$ & & & $\begin{array}{c}0.947 * * * \\
(0.478)\end{array}$ & & & & \\
\hline VarAssign=Low & & & & $\begin{array}{l}1.541^{*} \\
(0.824)\end{array}$ & & & \\
\hline
\end{tabular}




\begin{tabular}{|c|c|c|c|c|c|c|c|}
\hline Assignees $=1$ & & & & & $\begin{array}{l}1.391^{* *} \\
(0.626)\end{array}$ & & \\
\hline IntClass=Low & $\begin{array}{c}0.099 \\
(0.170)\end{array}$ & $\begin{array}{c}0.138 \\
(0.174)\end{array}$ & $\begin{array}{c}0.127 \\
(0.184)\end{array}$ & $\begin{array}{c}0.100 \\
(0.160)\end{array}$ & $\begin{array}{c}0.122 \\
(0.167)\end{array}$ & $\begin{array}{c}0.151 \\
(0.166)\end{array}$ & $\begin{array}{c}0.117 \\
(0.186)\end{array}$ \\
\hline TimeAppl=Low & $\begin{array}{c}0.199 \\
(0.151)\end{array}$ & $\begin{array}{c}0.206 \\
(0.157)\end{array}$ & $\begin{array}{c}0.215 \\
(0.165)\end{array}$ & $\begin{array}{c}0.183 \\
(0.143)\end{array}$ & $\begin{array}{c}2.333^{* * *} \\
(0.801)\end{array}$ & $\begin{array}{c}0.393^{* * *} \\
(0.152)\end{array}$ & $\begin{array}{l}0.318^{*} \\
(0.175)\end{array}$ \\
\hline TimeToday=Low & $\begin{array}{c}-2.574 * * * * \\
(0.197)\end{array}$ & $\begin{array}{c}-2.622 * * * * \\
(0.201)\end{array}$ & $\begin{array}{c}-2.613 * * * * \\
(0.212)\end{array}$ & $\begin{array}{c}-2.584^{* * * * *} \\
(0.185)\end{array}$ & $\begin{array}{c}-2.619 * * * * \\
(0.193)\end{array}$ & $\begin{array}{c}-2.823 * * * * \\
(0.199)\end{array}$ & $\begin{array}{c}-2.617^{* * * *} \\
(0.216)\end{array}$ \\
\hline LitRef=Below & & & & & & $\begin{array}{c}-0.752^{* * * * *} \\
(0.158)\end{array}$ & \\
\hline PatRef=Below & & & & & & & $\begin{array}{c}-0.370^{* *} \\
(0.175)\end{array}$ \\
\hline $\begin{array}{l}\text { Country = Spain } \\
\& \text { AssignCO=No } \\
\text { Firms }\end{array}$ & & $\begin{array}{c}2.338^{* * * * *} \\
(0.640)\end{array}$ & & & & & \\
\hline $\begin{array}{l}\text { Country is Spain } \\
\text { \& AssignRI=No } \\
\text { Res.Institute }\end{array}$ & & & $\begin{array}{c}-2.058^{* * * *} \\
(0.679)\end{array}$ & & & & \\
\hline $\begin{array}{l}\text { Country=Spain \& } \\
\text { FSize }<13,000\end{array}$ & & & & & $\begin{array}{l}1.086^{* *} \\
(0.425)\end{array}$ & $\begin{array}{c}1.282^{* * *} \\
(0.425)\end{array}$ & \\
\hline Cox\&Snell's R ${ }^{2}$ & 0.257 & 0.265 & 0.263 & 0.259 & 0.265 & 0.274 & 0.260 \\
\hline Nagelkerke's R ${ }^{2}$ & 0.368 & 0.381 & 0.377 & 0.372 & 0.380 & 0.393 & 0.373 \\
\hline McFadden's $\mathrm{R}^{2}$ & 0.248 & 0.258 & 0.255 & 0.251 & 0.258 & 0.268 & 0.252 \\
\hline Obs & 709 & 709 & 709 & 709 & 709 & 709 & 709 \\
\hline ChiSq & 210.326 & 218.734 & 216.464 & 212.578 & 218.483 & 226.794 & 213.472 \\
\hline Degr.Freedom & 5 & 7 & 7 & 7 & 8 & 7 & 6 \\
\hline$-2 \mathrm{LL}$ & 89.796 & 107.360 & 107.845 & 92.714 & 100.712 & 131.383 & 141.661 \\
\hline
\end{tabular}

Dependent variable is patent forward citation. Base category is the group of non-cited patents. Standard deviations are in parentheses. Two-tailed tests: ${ }^{* * * *} \mathrm{p}<0.001,{ }^{* * *} \mathrm{p}<0.01,{ }^{* *} \mathrm{p}<0.05,{ }^{*} \mathrm{p}<0.1$

With respect to the size of firms, coefficients range from -0.285 (in Model 7) to -0.564 (Model 4), meaning a $24.8 \%$ to $43.1 \%$ lower propensity for belonging to the group of cited patents, if they are from smaller assignees. Thus, Hypothesis H4, establishing that patents from larger assignees tend to be more valuable, is confirmed.

Thirdly, as expected from the theory, there is a strong and negative marginal effect for the newest patents, considering the time elapsed since the issue date (measured with variable TimeToday). In particular, coefficients show propensities reduced from $92.4 \%$ to $94.1 \%$ to be among the group of cited patents, in the case of those patents with fewer than 3.25 years since the date of grant. These results confirm Hypothesis H6.2, stating that the time from grant date is positively linked to the value of a patent.

With respect to the time from the application file date to the grant date, measured with TimeAppl, Models 5, 6 and 7 show that there is a statistically significant positive effect if this time is lower than the median (3.55 years). According to these coefficients, patents with a shorter time from application to grant have from 1.37 (as in Model 7) to 10.3 times higher propensity to belong to the group of cited, or more valuable, patents. Thus, Hypothesis 6.1, posing that this time is negatively linked to the value of a patent, is partially confirmed. In Models 1 to 4, the obtained regression coefficients are also positive for the lower time outcome, but remain non-significant. 
Therefore, considering both time lapses, in all models, regression coefficients of these two principal effects show that the shorter the time from application to grant, and the longer the time from grant to the present time, the higher the propensity a patent has to be among the group of cited patents.

Finally, the last main effect considered in all the models is the number of classifications of the patent. There is no significant evidence of this effect as stated in Hypothesis H7.

A detailed analysis of models 1 to 5 yields the effects of the types of assignees. In Model 2 the effect of AssignCO shows that, overall, there is a significantly lower propensity for patents not containing a corporate assignee to be among the cited patents. In particular, a coefficient of -1.254 , meaning a reduction of $71.5 \%$ to find a cited patent, if the patent has no firm among its assignees. However, here there is an important difference between the two countries compared, as shown by the interaction effect between Country=Spain and AssignCO=No. Firms. In particular, the coefficient of 2.338 means a positive effect of 10.36 times for the Spanish set if the assignees areentities other than firms, that is, universities or research institutes. Thus, controlling for the rest of the effects, in the case of the Spanish set, not finding any firm among its assignees, increases the odds to have a cited patent almost 3 times.

Model 3 corroborates this last observation as it considers the effect of the presence of a research institute among the assignees in a patent. The obtained coefficient of 0.947 means a general propensity of 2,6 times greater to have a cited patent if from non-research institutes. However, this outcome must be corrected with a negative interaction effect of -2.058 for the subset of Spanish assignees if there is no research institute among the assignees of a patent. The total effect of this variable in the Spanish set equals -1.111, meaning that the absence of a research institute among the assignees of a patent reduces the possibility of producing a cited patent by $67.1 \%$. Therefore, the results from models 2 and 3 partially confirm Hypothesis H3 stating that patents which have a research institute among their assignees are more valuable. This hypothesis is only confirmed for the Spanish case.

Model 4 considers the effect of the diversity of assignees, as measured by VarAssign. In particular, there is a positive coefficient of 1.541 when diversity is low, meaning a propensity of 4.67 times to be a cited patent when all the assignees are the same kind or if, as is the case of the majority of patents analyzed, there is only one assignee.

In order to differentiate this coincidence between the state of minimum variety of assignees and the number of assignees when there is only one, Model 5 tests the effect of the number of assignees (Assignees), in substitution of the variable VarAssign. The resulting coefficients show a positive effect when the patent has only one assignee (1.391, or about 4 times), compared to patents owned by 2 or more assignees. These coincident results from models 4 and 5, give significant evidence backing our hypothesis H1, stating that the number of assignees is negatively linked to its value, and $\mathrm{H} 2$ posing that the more diverse the assignees in a patent, the less valuable it is.

Models 5 and 6 share an interaction effect between the country and the size of the assignee. In both, there is a positive effect for the case of Spanish assignees belonging to smaller companies by number of workers. The obtained coefficients are respectively equal to 1.086 and 1.282. These results mean that patents from assignees that are Spanish and smaller than the median have from 2.96 to 3.60 more possibilities to belong to the group of cited patents. Thus, here we find a contradiction to the main effect obtained by size, as stated in hypothesis H4. 
Therefore, these results require further analysis. We are also recognizing that the division of size using a median of 13,000 employees does not provide a realistic or useful interpretation of the size effect on the value of patents for most firms, large or small. The Spearman's rank order correlation coefficients between size by number of employees and the number of forward citations within each country and the total gives further clearance (Table 3):

Table 3. Spearman's rank order correlations between the size of the biggest assignee and the number of forward citations

\begin{tabular}{|l|c|c|}
\hline & Spain & Germany \\
\hline & \multicolumn{2}{|c|}{ Number of forward citations } \\
\hline $\begin{array}{l}\text { Size of biggest assignee in } \\
\text { the patent (Employees) }\end{array}$ & $\begin{array}{c}\text { Rho }=-0.115^{*} \\
\left(\mathrm{n}_{\mathrm{Sp}}=209\right)\end{array}$ & $\begin{array}{c}\text { Rho }=0.118^{* * *} \\
\left(\mathrm{n}_{\mathrm{Ge}}=500\right)\end{array}$ \\
\cline { 2 - 3 } & \multicolumn{2}{|c|}{$\begin{array}{c}\mathrm{Rho}=0.126 * * * * \\
(\mathrm{n}=709)\end{array}$} \\
\hline
\end{tabular}

The Spearman's rank order correlations, linking the size of the biggest assignee with the number of forward citations, show opposite results: whereas in the German case, there is a positive link between size and number of forward citations, in the Spanish case this relation is negative. Therefore, Hypothesis $\mathrm{H} 4$ shows significantly contradictory results in both sets, being evidenced only in the case of the German set of patents.

In any case, these results leave room for further conjectures regarding the nature of organizations themselves and their partnerships in both sets. The negative correlation for the case of Spain is partly explained by the remarkable differences existing in the mean values of both analyzed countries and across all the types of assignees defined (Table 1, top part). More than $75 \%$ of the patents from the Spanish set are placed in the group of smaller assignees, having less than 13,000 employees. Secondly, only in the Spanish case is the presence of research institutes among the assignees of a patent associated with more forward citations, as seen from Model 3. In other words, it is observed in the Spanish set that patents have greater possibilities of becoming more valuable if there is a research institute among its assignees, or directly if the assignee is a research institute.

Additionally, there is more insight to be obtained in Model 5, from the positive interaction coefficient between assignee size and the country (equaling 1.086 for the case of the Spanish and smaller-firm subset), and the positive principal effect when there is only one assignee (equal to 1.391). Again, a comparison of the Spearman's rank order coefficients obtained (Table 4) gives different results in each set.

Table 4. Spearman's rank order correlations between the number of assignees in a patent and the number of forward citations

\begin{tabular}{|l|c|c|}
\hline & Spain & Germany \\
\hline \multirow{3}{*}{ Number of assignees } & \multicolumn{2}{|c|}{ Number of forward citations } \\
\cline { 2 - 3 } & $\begin{array}{c}\text { Rho }=-0.170 * * \\
\left(\mathrm{n}_{\mathrm{Sp}}=211\right)\end{array}$ & $\begin{array}{c}\text { Rho }=0.005 \\
\left(\mathrm{n}_{\mathrm{Ge}}=500\right)\end{array}$ \\
\cline { 2 - 3 } & \multicolumn{2}{|c|}{$\begin{array}{c}\text { Rho }=-0.057 \\
(\mathrm{n}=711)\end{array}$} \\
\hline
\end{tabular}


According to this result, in the Spanish case, the more assignees there are in a patent, the lower the number of forward citations. Linking these results with the previous review from hypothesis $\mathrm{H} 1$ to $\mathrm{H} 4$, there is some ground to conjecture that when patents are predicted to be more valuable, developers tend not to share them with other partners and develop them alone. On the contrary, if an idea has poorer prospects for reaching the market, then the incentive for opportunism from information asymmetries, that is, a potential "lemons" problem (Akerlof 1970, Pisano 1990) will exist, as the developer might be prompted to try to license the idea to collaborative partners to share the risks.

Thus, to summarize this evaluation of the effect of the number of assignees in a patent, the results obtained from linking the original variables confirm $\mathrm{H} 1$ albeit only for the case of the Spanish set. For the case of the German and total sets, no significant correlations were obtained .

Finally, models 6 and 7 consider the effects of scientific articles (LitRef) or the number of cited patents (PatRef), respectively. Model 6 shows there is a significant negative coefficient (equal to -0.752) for the group of patents containing a number of cited articles that is below the median. This effect diminishes the propensity for a patent to be cited by up to 52,9\%. Thus, Hypothesis H8.1 posing that the number of articles cited has a negative effect on the value of the patent is confirmed. Finally, Model 7 shows a significantly negative effect resulting from the number of cited patents $(-0.370)$, meaning a reduction of $31 \%$. These results confirm Hypothesis H8.2, stating that the number of cited patents has a significant negative effect on the patent value.

\section{Conclusions and implications for management and policy-making}

This study confirms that, for various reasons, big firms often use patents to protect intellectual property. Firstly, patenting is expensive and even more so when the procedure is handled at a foreign patent office. Secondly, patenting involves disclosing sensitive information and trusting a legal protection scheme that does not fully or effectively guarantee the intellectual property concerned. Thirdly, as a result of these limitations, firms usually have other means of safeguarding knowledge, like industrial secrecy (Teece, 1986, Mansfield et al. 1981).

On the other hand, in the case of this KET of advanced manufacturing technologies in robotics and automation, we have found that a patent is likely to be more valuable if the developer firm is large or belongs to a big group. In the sample analyzed, the value used as threshold was 13,000 employees. There is no doubt that this value corresponds to very large firms.

In addition to the size of the assignee, the country of origin was also found to be an important factor to predict the value of a patent. Patents prosecuted by Germany assignees have a greater likelihood of being more valuable than when the assignee is Spanish, regardless of the size of the applicant firm. Therefore, Germany not only has more patents than Spain, but we have found that they are also more valuable, in general terms, than Spanish patents for the same KET.

From the business management perspective, smaller firms have to resort to cooperation agreements to compensate for their size. However, this arrangement raises serious concerns due to the inevitable information asymmetries and the type of knowledge involved. These concerns prompt opportunistic behaviour and impose coordination and supervision costs. All of the above lead to poorer quality knowledge. At least for Spanish firms, which are smaller than German ones (with medians of 1,357 and 25,000 employees 
for this KET respectively), cooperation with technology centers and universities is a good option, in line with the argument conjectured in Hypothesis H3.

Furthermore, it has been proven that the time elapsed between the application and the grant date has an important effect on the value of a patent. It has been found that patents which took less time to receive approval are the ones that have more forward citations, regardless of the assignee's country. It can therefore be stated that it is worth it for firms to make efforts to file their patent applications correctly.

Similarly, we consider that our empirical analysis gives some insight into the study of Business-to-Business agreements and their effects on the joint development of intellectual property. In agreement with our results, it seems that having plural and diverse partners in a patent does not contribute to its value.

\section{Limitations and future lines of research}

In this research, we have taken patents as our element of analysis, controlling for the type of assignee, its relationships with other assignees and their size in number of employees. However, we have not focused on companies as a unit of analysis. Having focused on the company would have deviated us from our objectives. In return, we admit it would have allowed us to know firms' patent portfolios and understand in a more complete way their relationships through their portfolios. For example, this could have led us to understand better different phenomena such cross licensing or bargaining, among others, how the patent portfolio affects the value of a patent or how it affects the relationship between innovation and performance (Calantone et al, 2002).

On the other hand, this research provides some evidence in the sense that the size of the company's patent portfolio may be a factor in speeding up approval from the time the patent application is filed. However, we have not confirmed this point, and it would be a subject for study in the immediate future. The idea underlying this hypothesis is that patenting uses large amounts of management resources and is benefited from learning economies (Arrow 1962). Thus, it would be logical to think that with a stronger tradition in patenting, those firms owning bigger patent portfolios and having patented for longer, will tend to have patents of a better quality, as measured by the number of forward citations.

Finally, although we have proved that having plural and diverse partners in a patent does not contribute to its value. However, we understand that there are many relations requiring confirmation that are beyond the aims set for this study. We particularly refer to horizontal agreements between competitors, vertical agreements typical of supply chains or lateral agreements with research institutes, universities or foundations. Future studies should also focus on in-depth empirical analysis of these types of cooperation in industrial relations and B2B in the case of emerging technologies, as well as the reasons for which they arise.

\section{REFERENCES}

Acs, Z.J. and Audretsch, D.B. (1990), Innovation and Small Firms, Cambridge, Mass.: MIT Press.

Akerlof, G. (1970), The Market for "Lemons": Quality Uncertainty and the Market Mechanism. The Quarterly Journal of Economics, 84(3), 488-500. 
Alcácer, J., Gittelman, M. (2006), Patent Citations as a Measure of Knowledge Flows: The Influence of Examiner Citations. The Review of Economics and Statistics, 88(4), 774-779.

Almeida, P. (1996), Knowledge Sourcing by Foreign Multinationals: Patent Citation Analysis in the U.S. Semiconductor Industry. Strategic Management Journal, 17, 155-165.

Altshuller, G. (2007), The Innovation Algorithm. TRIZ, Systematic Innovation and Technical Creativity. Worcester (MA): Technical Innovation Center, Inc.

Arrow (1962), Economic Welfare and the Allocation of Resources for Invention. In The Rate and Direction of Inventive Activity: Economic and Social Factors. NBER. 609626. http://www.nber.org/chapters/c2144

Arundel, A. (2001), The relative effectiveness of patents and secrecy for appropriation. Research Policy 30(4), pp.611-624

Aschhoff, B, Crass, D., Cremers, K., Grimpe, C., Rammer, C., Brandes, F., Diaz-Lopez, F, Woolthuis, R.K., Mayer, M., Montalvo, C. (2010) European Competitiveness in Key Enabling Technologies. ZEW, TNO. http://www.manufuture.org/wpcontent/uploads/Final_report_07.06.10_KETs_Background_Report_2010_05_28. pdf.

Barney, J. (1986), Organizational Culture: Can It Be a Source of Sustained Competitive Advantage? The Academy of Management Review, 11(3), 656-665.

Barney, J. (2001), Is the Resource-Based "View" a Useful Perspective for Strategic Management Research? Yes. The Academy of Management Review, 26(1), 41-56.

Belderbos, R., Sleuwaegen, L., Somers, D., De Backer, K. (2016), Where to Locate Innovative Activities in Global Value Chains: Does Co-location Matter?, OECD Science, Technology and Industry Policy Papers, No. 30, OECD Publishing, Paris. http://dx.doi.org/10.1787/5jlv8zmp86jg-en

Bound, John, Cummings, Clint, Griliches, Zvi, Hall, Bronwyn H., and Jaffe Adam.(1984), "Who DoesR \& D and Who Patents?”. Chapter from Griliches, Z. (Ed.) R\&D, Patents, and Productivity. Chicago: University of Chicago Press, pp.2154.

Bresnahan, T., Trajtenberg, M. (1995), General purpose technologies 'Engines of growth'? Journal of Econometrics, 65 (1), 83-108

Butter, M., Fischer, N., Gijsbers, G., Hartmann, C., de Heide, M., van der Zee, F. (2014) Horizon 2020: Key Enabling Technologies (KETs),Booster for European Leadershipin the Manufacturing Sector. Committee on Industry,Research and Energy. European Union. http://www.europarl.europa.eu/studies

Chesbrough, H. (2011), Open Services Innovation: Rethinking Your Business to Grow and Compete in a New Era, San Francisco (CA): Wiley.

Cohen, W., Levinthal, D. (1989), Innovation and Learning: The Two Faces of R, D. The Economic Journal, 99 (397), 569-596. doi:10.2307/2233763

Cohen, W., Levinthal, D. (1990), Absorptive Capacity: A New Perspective on Learning and Innovation. Administrative Science Quarterly, 35(1), 128-152. doi:10.2307/2393553

Dahlander, L., Gann, D.M. (2010), How open is innovation? Research Policy, 39, 699709.

Dosso, M., Vezzani, A. (2015), Top R\&D Investors and international knowledge seeking: the role of emerging technologies and technological proximity. JRC-IPTS, European Commission, Seville, Spain.

Doi, N. (1996). Performance of Japanese Firms in Patented Inventions; an Analysis of Patents Granted in the U.S. Review of Industrial Organization, 11(1), 49-68. 
Dyer, J., Singh, H. (1998), The Relational View: Cooperative Strategy and Sources of Interorganizational Competitive Advantage. The Academy of Management Review, 23(4), 660-679.

European Commission (2014), Communication from the Commission to the European Parliament, the Council, the European Economic and Social Committee and the Committee of the Regions for a European Industrial Renaissance. Document 52014DC0014. Brussels, January 22. Permanent link: http://eur-lex.europa.eu/legalcontent/EN/TXT/?uri=CELEX:52014DC0014

Griliches, Z. (1981) Market value, R\&D, and patents, Economics Letters, 7, (2),183-187

Hall, B., Jaffe, A., Trajtenberg, M. (2005), Market Value and Patent Citations. The RAND Journal of Economics, 36(1), 16-38.

Harhoff, D., Narin, F., Scherer, F., Vopel, K. (1999), Citation Frequency and the Value of Patented Inventions. The Review of Economics and Statistics, 81(3), 511-515

Harhoff, D., Scherer, F., Vopel, K. (2003), Citations, family size, opposition and the value of patent rights. Research Policy, 32, 1343-1363

Hidalgo, C.A., Klinger, B., Barabási, A., Hausmann, R. (2007), The product space conditions the development of nations. Science, 317(5837), 482-487.

Iversen, E. (2003), Norwegian Small and Medium-Sized Enterprises and the Intellectual Property Rights System: Exploration and Anlysis. STEP Center for Innovation Policy. https://eprints.utas.edu.au/1358/1/Iversen2003WipoStudy.pdf

Jaffe, A.B., Rassenfosse, G. (2017), Patent Citation Data in Social Science Research: Overview and Best Practices. Journal of the Association for Information Science and Technology, 68(6),:1360-1374

Katila, R. (2002), New Product Search over Time: Past Ideas in Their Prime? The Academy of Management Journal, 45(5), 995-1010.

Kline, S.J., Rosenberg, N. (1986), An overview of innovation, in: R. Landau, N. Rosenberg (Eds.), The Positive Sum Strategy: Harnessing Technology for Economic Growth, National Academy Press, Washington, D.C.

Larsen, P.B., Van de Velde, E., Durinck, E., Piester, H.N., Jakobsen, L., Shapiro, H. (2011), Cross-sectoral Analysis of the Impact of International industrial Policy on Key Enabling Technologies. European Commission, DG Enterprise and Industry.

Lerner, J. (1994), The Importance of Patent Scope: An Empirical Analysis. The RAND Journal of Economics, 25 (2), 319-333.

Lerner, J., Seru, A. (2017), The use and misuse of patent data: Issues for corporate finance and beyond. Working Paper 18-042. Harvard Business School

Lipsey, RG., Carlaw, K., Bekar, C. (1995), Economic transformations: general purpose technologies and long-term economic growth. Oxford University Press. Oxford.

Mansfield, E., Schwartz, M., \& Wagner, S. (1981). Imitation Costs and Patents: An Empirical Study. The Economic Journal, 91(364), 907-918. doi:10.2307/2232499

Merges, R., Nelson, R. (1990), On the Complex Economics of Patent Scope. Columbia Law Review, 90(4), 839-916. doi:10.2307/1122920

Michel, J., Bettels,B. (2001), Patent citation analysis A closer look at the basic input data from patent search reports. Scientometrics, 51(1), 185-201

Montresor, S., Quatraro, F. (2017), Regional Branching and Key Enabling Technologies: Evidence from European Patent Data. Economic Geography, 93 (4),367-396.

OECD (2009), OECD Patent Statistics Manual. Paris.

Dernis, H., Dosso, M., Hervás, F., Millot V., Squicciarini M., Vezzani A. (2015), World Corporate Top R\&D Investors: Innovation and IP bundles. A JRC and OECD common report. Luxembourg. Publications Office of the European Union. 
Daiko T.\& Dernis H., Dosso M., Gkotsis P., Squicciarini M., Vezzani A. (2017), World Corporate Top $R \& D$ Investors: Industrial Property Strategies in the Digital Economy. A JRC and OECD common report. Luxembourg: Publications Office of the European Union

Patel, P., and Pavitt, K. (1991). Large Firms in the Production of the World's Technology: An Important Case of "Non-Globalisation". Journal of International Business Studies, 22(1), 1-21.

Peteraff, M.A. (1993), The cornerstones of competitive advantage: A resource-based view. Strategic Management Journal, 14 (3), 179-191

Petruzzelli, A.M., Ardito, L., Savino, T. (2018), Maturity of knowledge inputs and information value: The moderation effect of firm age and size, Journal of Business Research, 86, 190-201.

Pisano, G.(1990), R\&D Performance, Collaborative Arrangements, and the Market-forKnow-How: A Test of the "Lemons" Hypothesis in Biotechnology. Mimeo.

Porter, M.E. (1990), The competitive advantage of nations. Harvard Business Review, 68 (2), 73-91.

Rogers, E.M. (1983), Diffusion of Innovations. Third Edition. New York: The Free Press

Rogers, E. M. (1989), The intellectual foundations and history of the agricultural extension model. Knowledge, 9, 492-510.

Rogers, E.M. (2002), The Nature of Technology Transfer. Science Communication, Vol. 23 No. 3 (March), 323-341

Rotolo, D., Hicks, D., Martin, B. (2015), What Is an Emerging Technology?. Research Policy, 44, (10), 1827-1843

Scalia, T., Di Mezza, A., Masini, A., Sylvestre, S., Thomas, R., De Heide, M., Butter, M., Parker, D. (2017), Study on the Dual-Use Potential of Key Enabling Technologies (KETs), Prepared for the European Commission — EASME, available at https://publications.europa.eu/en/publication-detail/-/publication/c092b731-f41511e6-8a35-01aa75ed71a1, doi:10.2826/12343

Schiessler, P.M. (2015), Patent litigation and firm performance: the role of the enforcement system. Industrial and Corporate Change, 24, (2), 307-343

Spithoven, A., Vanhaverbeke, W., Roijakkers, N. (2013), Open innovation practices in SMEs and large enterprises. Small Business Economics, 41(3), 537-562.

Sörvik, J., Rakhmatullin, R. \&Palazuelos-Martínez, M. (2013), Preliminary report on KETs declared by regions in the context of their work on Research and Innovation Strategies for Smart Specialisation (RIS3), European Commission. Joint Research Centre Institute for Perspective Technological Studies.Luxembourg: Publications Office of the European Union. Doi: 10.2791/22913

Teece, D.J. (1986), Profiting from technological innovation:Implications for integration, collaboration, licensing and public policy, Research Policy, 15(6), 285-305.

Trajtenberg, M., Henderson, R., Jaffe, A. (1997), University Versus Corporate Patents: A Window On The Basicness Of Invention. Economics of Innovation and New Technology, 5 (1), 19-50, DOI: 10.1080/10438599700000006

Tsuji, M., Ueki, Y., Shigeno, H., Idota, H., Bunno, T. (2018), R\&D and non-R\&D in the innovation process among firms in ASEAN countries: Based on firm-level survey data. European Journal of Management and Business Economics, 27 (2), 198-214,

Van de Vrande, V., de Jong, J., Vanhaverbeke, W., De Rochemont, M. (2009), Open innovation in SMEs: Trends, motives and management challenges. Technovation, 29 (6-7), 423-437.

Van de Velde, E., Debergh, P., Rammer, C., Schliessler, P., Gehrke, B., Wassmann, P., de Heide, M., Butter, M., Wydra, S., Som, O., Weidner, N. (2015), Key Enabling 
Technologies (KETs) Observatory. Methodology Report. European Commission, Directorate-General for Internal Market, Industry, Entrepreneurship and SMEs.

van Raan, A.F.J.(2017), Patent Citations Analysis and Its Value in Research Evaluation:

A Review and a New Approach to Map Technology-relevant Research. Journal of Data and Information Science, 2, (1), 13-50.

Verspagen, B. (2000), The role of large multinationals in the Dutch technology infrastructure: a patent citation analysis. Scientometrics, 47 (2), 427-448.

Von Hippel, E., (1988), Sources of Innovation. Oxford University Press, Oxford.

WIPO (2017), World Intellectual Property Indicators 2017. Geneva: World Intellectual Property Organization.

Wynarczyk, P., Piperopoulos, P., McAdam, M. (2013), Open innovation in small and medium-sized enterprises: An overview. International Small Business Journal, 31(3), 240-255

Zahra, S.A., George, G. (2002), Absorptive Capacity: A Review, Reconceptualization, and Extension. Academy of Management Review, 27 (2), 185-203

\begin{tabular}{|c|c|c|}
\hline \multicolumn{3}{|c|}{ APPENDIX 1: Relations between KETs and patents IPC } \\
\hline IPC Code & $\begin{array}{l}\text { Field of } \\
\text { Technology }\end{array}$ & Description \\
\hline B03C & $\begin{array}{l}\text { Chemical } \\
\text { Engineering }\end{array}$ & $\begin{array}{l}\text { MAGNETIC OR ELECTROSTATIC SEPARATION OF } \\
\text { SOLID MATERIALS FROM } \\
\text { FLUIDS; SEPARATION BY HIGH-VOLTAGE ELECTRIC } \\
\text { FIELDS }\end{array}$ \\
\hline B06B & $\begin{array}{l}\text { Chemical } \\
\text { Engineering }\end{array}$ & $\begin{array}{l}\text { GENERATING OR TRANSMITTING MECHANICAL } \\
\text { VIBRATIONS IN GENERAL }\end{array}$ \\
\hline \multicolumn{3}{|l|}{$\begin{array}{l}\text { В06B00016 } \\
\text { В06B000300 }\end{array}$} \\
\hline B07C & $\begin{array}{l}\text { Chemical } \\
\text { Engineering }\end{array}$ & $\begin{array}{l}\text { POSTAL SORTING; SORTING INDIVIDUAL ARTICLES, } \\
\text { OR BULK MATERIAL FIT TO BE SORTED PIECE-MEAL, } \\
\text { e.g. BY PICKING }\end{array}$ \\
\hline $\mathrm{B} 23 \mathrm{H}$ & $\begin{array}{l}\text { Machine } \\
\text { tools }\end{array}$ & $\begin{array}{l}\text { WORKING OF METAL BY THE ACTION OF A HIGH } \\
\text { CONCENTRATION OF ELECTRIC CURRENT ON A } \\
\text { WORKPIECE USING AN ELECTRODE WHICH TAKES } \\
\text { THE PLACE OF A TOOL; SUCH WORKING COMBINED } \\
\text { WITH OTHER FORMS OF WORKING OF METAL }\end{array}$ \\
\hline B23K & $\begin{array}{l}\text { Machine } \\
\text { tools }\end{array}$ & $\begin{array}{l}\text { SOLDERING } \text { OR UNSOLDERING; WELDING; } \\
\text { CLADDING OR PLATING BY SOLDERING OR } \\
\text { WELDING; CUTTING BY APPLYING HEAT LOCALLY, } \\
\text { e.g. FLAME CUTTING; WORKING BY LASER BEAM }\end{array}$ \\
\hline B23P & $\begin{array}{l}\text { Machine } \\
\text { tools }\end{array}$ & $\begin{array}{lcccc}\text { OTHER } \quad \text { WORKING } & \text { OF } & \text { METAL; } & \text { COMBINED } \\
\text { OPERATIONS; UNIVERSAL MACHINE TOOLS }\end{array}$ \\
\hline B23Q & $\begin{array}{l}\text { Machine } \\
\text { tools }\end{array}$ & $\begin{array}{l}\text { DETAILS, COMPONENTS, OR ACCESSORIES FOR } \\
\text { MACHINE TOOLS, e.g. ARRANGEMENTS FOR COPYING } \\
\text { OR CONTROLLING (tools of the kind used in lathes or boring } \\
\text { machines B23B 27/00); MACHINE TOOLS IN GENERAL, } \\
\text { CHARACTERISED BY THE CONSTRUCTION OF } \\
\text { PARTICULAR DETAILS OR COMPONENTS; } \\
\text { COMBINATIONS OR ASSOCIATIONS OF METAL- } \\
\text { WORKING MACHINES, NOT DIRECTED TO A } \\
\text { PARTICULAR RESULT }\end{array}$ \\
\hline
\end{tabular}




\begin{tabular}{|c|c|c|}
\hline B25J & Handling & 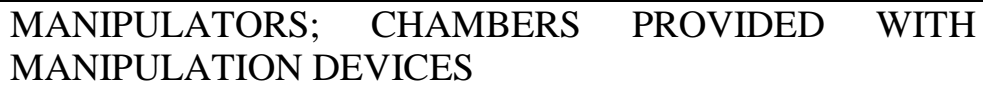 \\
\hline G01D & $\begin{array}{l}\text { Measureme } \\
\text { nt }\end{array}$ & $\begin{array}{l}\text { MEASURING NOT SPECIALLY ADAPTED FOR A } \\
\text { SPECIFIC } \\
\text { FOR MEASURING TWO OR MORE VARIABLES NOT } \\
\text { COVERED BY A SINGLE OTHER SUBCLASS; TARIFF } \\
\text { METERING APPARATUS; TRANSFERRING } \text { OR } \\
\text { TRANSDUCING ARRANGEMENTS NOT SPECIALLY } \\
\text { ADAPTED FOR A SPECIFIC VARIABLE; MEASURING } \\
\text { OR TESTING NOT OTHERWISE PROVIDED FOR }\end{array}$ \\
\hline G01F & $\begin{array}{l}\text { Measureme } \\
\text { nt }\end{array}$ & $\begin{array}{l}\text { MEASURING VOLUME, VOLUME FLOW, MASS FLOW, } \\
\text { OR LIQUID LEVEL; METERING BY VOLUME [ }\end{array}$ \\
\hline G01H & $\begin{array}{l}\text { Measureme } \\
\mathrm{nt}\end{array}$ & $\begin{array}{l}\text { MEASUREMENT OF MECHANICAL VIBRATIONS OR } \\
\text { ULTRASONIC, SONIC OR INFRASONIC WAVES }\end{array}$ \\
\hline G01L & $\begin{array}{l}\text { Measureme } \\
\text { nt }\end{array}$ & $\begin{array}{l}\text { MEASURING FORCE, STRESS, TORQUE, WORK, } \\
\text { MECHANICAL POWER, MECHANICAL EFFICIENCY, OR } \\
\text { FLUID PRESSURE }\end{array}$ \\
\hline G01M & $\begin{array}{l}\text { Measureme } \\
\text { nt }\end{array}$ & $\begin{array}{lcccc}\text { TESTING STATIC } & \text { OR } & \text { DYNAMIC } & \text { BALANCE } & \text { OF } \\
\text { MACHINES } & \text { OR } & \text { STRUCTURES; TESTING OF } \\
\text { STRUCTURES } & \text { OR APPARATUS, NOT } & \text { OTHERWISE } \\
\text { PROVIDED FOR } & & & \end{array}$ \\
\hline G01P & $\begin{array}{l}\text { Measureme } \\
\text { nt }\end{array}$ & $\begin{array}{l}\text { MEASURING LINEAR OR ANGULAR } \\
\text { ACCELERATION, DPEED, DECELERATION OR } \\
\text { INDICATING PRESENCE OR ABSENCE OF MOVEMENT; } \\
\text { INDICATING DIRECTION OF MOVEMENT }\end{array}$ \\
\hline G01Q & $\begin{array}{l}\text { Measureme } \\
\text { nt }\end{array}$ & 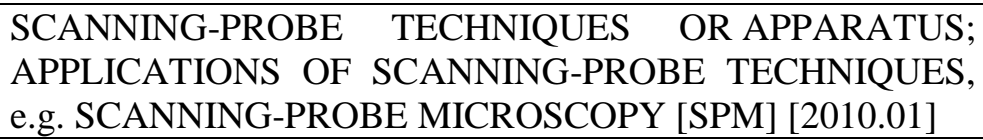 \\
\hline G05B & Control & $\begin{array}{l}\text { CONTROL OR REGULATING SYSTEMS IN GENERAL; } \\
\text { FUNCTIONAL ELEMENTS OF SUCH SYSTEMS; } \\
\text { MONITORING OR TESTING ARRANGEMENTS FOR } \\
\text { SUCH SYSTEMS OR ELEMENTS }\end{array}$ \\
\hline G05D & Control & $\begin{array}{l}\text { SYSTEMS FOR CONTROLLING OR REGULATING NON- } \\
\text { ELECTRIC VARIABLES }\end{array}$ \\
\hline G05F & Control & $\begin{array}{l}\text { SYSTEMS FOR REGULATING ELECTRIC OR MAGNETIC } \\
\text { VARIABLES }\end{array}$ \\
\hline G05G & $\begin{array}{l}\text { Mechanical } \\
\text { elements }\end{array}$ & $\begin{array}{llll}\text { CONTROL DEVICES OR } & \text { SYSTEMS } & \text { INSOFAR } & \text { AS } \\
\text { CHARACTERISED } & & & \text { BY } \\
\text { MECHANICAL FEATURES ONLY } & & \\
\end{array}$ \\
\hline G06M & $\begin{array}{l}\text { Computer } \\
\text { technology }\end{array}$ & $\begin{array}{l}\text { COUNTING MECHANISMS; COUNTING OF OBJECTS } \\
\text { NOT OTHERWISE PROVIDED FOR }\end{array}$ \\
\hline G07C & Control & $\begin{array}{l}\text { TIME OR ATTENDANCE REGISTERS; REGISTERING OR } \\
\text { INDICATING THE WORKING OF MACHINES; } \\
\text { GENERATING RANDOM NUMBERS; VOTING OR } \\
\text { LOTTERY APPARATUS; ARRANGEMENTS, SYSTEMS } \\
\text { OR APPARATUS FOR CHECKING NOT PROVIDED FOR } \\
\text { ELSEWHERE }\end{array}$ \\
\hline G08C & $\begin{array}{l}\text { Telecommu } \\
\text { nications }\end{array}$ & $\begin{array}{l}\text { TRANSMISSION SYSTEMS FOR MEASURED VALUES, } \\
\text { CONTROL OR SIMILAR SIGNALS }\end{array}$ \\
\hline
\end{tabular}

